\section{ECONOMICS}

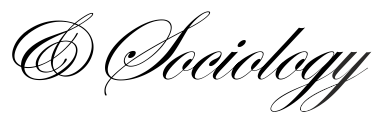

Maloku, S., Cera, G., Poleshi, B., Lushi, I., \& Metzker, Z. (2021). The effect of relationship quality on contract farming: The mediating role of conflict between trading partners in Albania. Economics and Sociology, 14(3), 283-296.

doi:10.14254/2071-789X.2021/14-3/15

\title{
THE EFFECT OF RELATIONSHIP QUALITY ON CONTRACT FARMING: THE MEDIATING ROLE OF CONFLICT BETWEEN TRADING PARTNERS IN ALBANIA
}

Sadik Maloku

Faculty of Life and Environmental

Sciences, University 'Ukshin Hoti”,

Prizren, Kosovo

E-mail:sadik.maloku@uni-

prizren.com

\section{Gentjan Çera}

Faculty of Management and

Economics, Tomas Bata University,

Crech Republic

E-mail: cera@utb.cr.

ORCID 0000-0002-9324-181X

\section{Bekim Poleshi}

Faculty of Economics and Administrative Sciences, Epoka

University, Albania

E-mail:bpolesbi19@epoka.edu.al

\section{Isuf Lushi*}

Faculty of Life and Environmental

Sciences, University "Ukshin Hoti"

Prizenen, Kosovo

*Corresponding author

E-mail:isuf.lushi@uni-prizren.com

\section{Zdenko Metzker}

Faculty of Management and

Economics, Tomas Bata University,

Crech Republic

E-mail:metzken@utb.cr.

Received: November, 2020

1st Revision: May, 2021

Accepted: September, 2021
ABSTRACT. The aim of this research paper is to explore the role of conflict between trading partners in terms of relationship quality (satisfaction, commitment, and trust) on contract farming. Even though there is research on the above issues, yet there is lack of research on the role of conflict between partners in terms of relationship quality on contract farming. Thus, there is a need to offer evidence that brings more clarity to such a role of conflict between trading partners. To test the hypothesized relationships, primary data are collected in different agribusiness areas in Albania. Altogether, 640 successful questionnaires are filled in. The relationships are tested using the partial least squares of structured equation modelling (PSL-SEM) method. The key finding is that a conflict between trading partners influences contract farming and mediates the effects of the farmer's satisfaction and trust in the relationship with their buyer on contract farming. This paper enriches the existing literature, since it provides additional insights from a developing country context. 


\begin{abstract}
JEL Classification: Q12, Q13 Keywords: satisfaction, commitment, trust, contract farming, relationship quality, conflict, PLS-SEM
\end{abstract}

\title{
Introduction
}

Globalization is increasing rapidly, and its effects are being widely noticeable in every field of life. In terms of transactions, markets, relationships between buyers and sellers, banking products, financial access, and other similar concepts, this has led to an increasing level of development, complexity, and dynamism. In the global economy, it is a noticeable trend towards formalization in all sectors (Muo \& Azeez, 2019). This paper concerns the so-called green economy. Agriculture is the main booster of Albanian economy. In this context, the relationship quality between farmers and buyers, the importance of contract farming, and trading conflicts are of high priority for researchers, scholars, academicians, and policy makers.

Contract farming is not something new as it has existed for decades. In Albania, contract farming is not widespread as the majority of farmers are oriented to 'spot-markets' transactions instead, without any type of prior written or verbal agreement (Keco et al., 2019). From a wider perspective, this is usually related to low levels of financial behaviour and this panorama is similar in most of the Albanian economic sectors, not only in agriculture. However, in a place where agriculture has the biggest influence on its GDP, the importance of contract farming cannot be put in doubt. In this context, there is a need for better insight into the advantages and disadvantages of contract farming, along with its relationships with conflict or concepts like satisfaction, trust, and commitment. Of course, contract farming has its own advantages and disadvantages. In order to make the most out of these trading forms, there has to be a 'win-win' situation for both farmers and buyers (Birthal, 2008; Evteeva et al., 2019; Kóródi \& Dávid, 2019).

Contract farming is often considered as a means of increasing welfare. Bellemare (2012) in his study expects contract farming to have an increasing importance in developing countries in the future. Simmons (2002) shares the same point of view, however argues that there is not a sufficient condition for such improvement. To go further in his logic, he points out that small farmers may be discriminated against because the selection process from agribusiness firms may be biased. Daviron (2002) is on the same logic line as he states that large buyers can exploit small farmers because of their power. Contrary to small ones, large farmers are believed to have better access to credit and other banking products, better information about production and marketing methods, and higher level of risk tolerance. In this context, institutional intervention is suggested to pursue policies that address such kinds of problems. In the literature, especially in the recent studies, it has also been noticed an increasing interest on the conflict between farmers and buyers caused by the level of satisfaction, commitment, and trust as well as the relationship of this conflict with contract farming.

Motivated by the above research gaps and needs, this study seeks to identify the role of conflict between farmers and buyers in terms of relationship quality (satisfaction, commitment and trust) on contract farming.

The paper is organised in five sections in addition to this one. The second section consists of the literature review. The third section describes the methods and procedures used for this research. The fourth section reflects the analysis and results. After the discussion of the results, the conclusion section ends the paper. 


\section{Literature review}

\subsection{Relationship quality}

Many researchers have investigated the relationship between farmers and buyers, as well as the influencing factors. The majority of them consider satisfaction, commitment, and trust to be core components in such a relationship. These theoretical factors are often seen as one because of the strong correlation between each other, but are also heavily linked with contract farming. In the literature there can be found many definitions for contract farming, varying from country to country. Grosh (1994) was among the first to study contract farming and defines it as an efficient and beneficial way of reducing transaction costs. The most widely used definition generally refers to contract farming as an agricultural production which is carried out according to an agreement between a buyer and farmers where there are established conditions for the production and marketing of a farm product or products (Wang et al., 2014). Contract farming, as a tool of formal markets, is shown to have a great impact on farmers' level of satisfaction, trust, and commitment. Dlamini-Mazibuko et al. (2019) indicate that farmers who operate in formal markets are shown to perceive better levels of satisfaction, trust, and commitment, compared to those who operate in informal markets. The authors support the idea that satisfaction and trust were among the best indicators of a trading relationship quality. However, they argue that the lack of written contracts contributes to the low-level farmer-buyer relationship quality.

Relationship between satisfaction and contract farming has received much attention in the past decade. Satisfaction is a psychological factor that indicates a feeling of contentment and gratification that arises when needs or desires have been fulfilled (Hartmann et al., 2010; Bencsik et al., 2018). To put it in this paper's perspective, relationship satisfaction refers to those cases when the performance between two or more trading parties exceeds their expectations (Batt \& Rexha, 2000). Farmers in Albania are generally oriented towards spot market transactions rather than contract farming. However, many authors argue that farmers who base their trading on written/verbal agreements enjoy higher levels of satisfaction compared to other farmers. Keco et al. (2019) are in the same line as they show that farmers operating with contracts, tend to have higher levels of satisfaction with the trading relationship than farmers operating on the traditional markets. Another great point of view is the one that relates satisfaction to interpersonal trust. In this context, Lu et al. (2012) argue that interpersonal trust implies a moderating effect on the trading relationship satisfaction. On the other hand, many authors claim that satisfaction may also be affected by changes in production process (e.g., Ik \& Azeez, 2020). This relationship is supported by the idea that it creates more pressure and leads to more efforts from farmers. Dedehouanou et al. (2013) is in the same line as in his study, he states that contract farming increases satisfaction because of aspects like reduced marketing risk, increased access to inputs and credit, and better access to improved technologies.

Another important influencing factor when it comes to contract farming is commitment. Macchiavello and Morjaria (2015) in their study relate buyers' higher commitment levels to better ability from the farmers to plan their production activities. Farmers' commitment in a trading relationship can change influenced by many factors. For example, Xhoxhi et al. (2014) argue that farmers' commitment is high when there is a kind of equilibrium between market conditions and contracting terms. Partners in a trading relationship may indicate their commitment by providing resources dedicated to the contract (Naidu, 2016). In the literature, farmers' commitment to the trading relationship is positively linked with participating in contract farming. 
Trust in a trading relationship is an asset that creates benefit (Bencsik et al., 2020; Çera et al., 2019; Gorb, 2017; Masuku \& Kirsten, 2004; Tarí et al., 2020). On the other hand, trust helps in reducing performance uncertainty and plays a vital role in a relational transaction (Alkhurshan \& Rjoub, 2020; Li \& Nicholls, 2000). For this reasons creation of the relationship based on a trust and mutual responsibility becomes important component of the current supply chain management (Kot et al., 2020; Vo et al., 2020) as well as internal management systems (Bilan et al., 2020). The entrepreneurial practices prove the positive influence of interpersonal and interorganizational trust on financial performance (Oláh et al., 2021). There are a variety of factors that can influence trust. Fritz and Fischer (2007) in their empirical study show that trust level in a trading relationship has a strong positive correlation with good communication between buyers and sellers. Other authors have highlighted the importance of trust in a trading relationship, especially when it comes to sensitive cases like food safety concerns (e.g. Kelić et al., 2020). Logically, a business transaction would likely not occur if there existed a lack of trust. In the literature, trust is considered the most important part of contract farming. Zhang and $\mathrm{Hu}$ (2011) in their study are in favour of the idea that contracts and trust are complementary to each other. Contracts are considered as a safeguard for the business, minimizing the potential negative consequences from the turbulence of the market.

Based on the above discussion, the following hypotheses can be formulated:

H1: Contract farming is positively affected by satisfaction (H1a), commitment (H1b), and trust (H1c) in the relationship with a buyer.

\subsection{Conflict between trading partners}

A very interesting point of view from the literature of the field is related to the potential conflict that can be caused by contract farming. Generally, the authors associate contract farming with many benefits, financial or not. For example, a number of authors believe that contracts help famers in obtaining loans easier and this serves as an incentive to sign these types of contracts. Keco et al. (2019) are in the same logic line as in their study, they show that contract farming helps in increasing farmers' level of income. Furthermore, the authors argue that a contract may offer more security for the intermediaries to give the farmers some other opportunities for cooperation. Another reason for the popularity of contract farming is that these contracts could link small farmers to high value agricultural commodity chains (Xhoxhi, Stefanllari, Skreli, \& Imami, 2020). However, contract farming is also linked to different kinds of risk because of the dynamic socio-economic environment and the variety of uncontrollable factors that act on it. As a consequence, there is an increased opportunity for farmers to be affected by a potential future conflict (Wang, Zhang, \& Wu, 2011). To mitigate it, the preventive measures like risk management systems can be implied (Polinkevych et al., 2021). In a situation where farmers successfully achieve to manage the risk, then contract farming would be a great opportunity to prevent or minimize the conflicts.

Theoretically, the satisfaction level that connects the business to a costumer or to another business, may cause further development of a company or the opposite of it (Piricz, 2018). Nonparticipation of these components in the whole process, starting by product characteristics until the passage of that into costumers hands, causes dissatisfaction. In the best scenario, this leads to untrusting relationships and in the worst scenario this leads to conflict (Xhoxhi et al., 2018). In other words, the conflict between trading partners increases and the relationship performance decreases. Shamdasani and Sheth (1994) emphasize that "satisfaction has been identified as a key variable in the decision of a business to remain in a business-tobusiness relationship, where parties secure high levels of satisfaction during each business transaction". Laeequddin (2012) has spotted that in a relationship, a partner's level of satisfaction is affected by previous connections based on trust predictions. Attention to this case 
is extended because satisfaction is that part of the buyer-supplier relational experience where the parties decide to continue with the relationship or not (Clampit et al., 2015). Voldnes et al. (2012) have pointed out that trust is cross-linked with satisfaction because higher levels of trust enhance overall satisfaction assumption, and more importance of long-term commitment.

Partnership relationships require the contribution of both parties. That is the reason why farmers and intermediaries want to commit the costumers too in their process (Kanji \& Wong, 1999). The commitment of every party to a common work reduces the workload for each party and increases the desire for cooperation (Wong, Tjosvold \& Zhang, 2005). On the other hand, the division of responsibility may lead on abuse from any party by passing their part of commit to others. There is where the conflict may appear and have consequences like disrupting the parties, lowering the efficiency, and increasing the costs for the farmer (Griffith et al., 2000). In this way, it is vital for each party to contribute to the final farmers' products. If one of the parties shows signs of noncommitment to the trading relationship, the other party will get disappointed and this can lead to conflict with unintended consequences (Wong et al., 2005). In this context, it is fair to say that higher levels of commitment imply a stronger buyer-seller relationships (Kaur et al., 2010).

In the literature, the conflict between buyers and seller is shown to have a significant negative correlation with trust. This logic is true also in the agricultural sector, more concretely, in the relationship between farmers and buyers. Xhoxhi et al. (2018) points out the fact that in developing countries, farmers may leave their production on the field if the price offered by intermediaries is too low. Logically, this leads to a potential conflict. Just by analogy, Williamson (1979) in his early study stated that low prices led to conflict between farmers and intermediaries and consequently, farmers would harvest the crop without selling their products. This conflict may cause a chain of consequences arising from distrust by intermediaries that trigger farmers to take the lead in their own hands. In this way, this process would derive negative implications for the farmers like weak work coordination as well as increased risks and costs as long as they keep their harvest in stock (Xhoxhi et al., 2018). However, keeping the harvest for a long time in the warehouse may be fatal for the farmers knowing the product characteristics and their sensitivity. Johnston et al. (2004) argue that keeping the products in the warehouse for a long time reduces the quality and in that way, the costs of farmers will increase, so this justifies the higher prices in the market. On the other hand, if the intermediaries would think of extracting profits for all parties, including farmers, intermediaries, and customers, the conflict might get lower (Xhoxhi et al., 2014). Farmers would trust their product to the intermediaries more than in the first case when intermediaries focus only on their own benefits and "squeeze" farmers' margin. In this way, their burden would be lightened according to product management.

Based on the above discussion, the following hypotheses can be formulated:

H2: Contract farming is positively influenced by the conflict between a farmer and its main buyer.

H3: The effects of relationship quality (satisfaction, H3a; commitment, H3b; trust, H3c) on contract farming is mediated by the conflict in the relationship.

The novelty of this research lies on the fact that the role of conflict on the relationships between satisfaction, commitment, and trust (collectively) and contract farming has not received enough attention in research. The present research aims to contribute to the literature in this regard.

\section{Methodological approach}

Materials and Methods should be described with sufficient details to allow others to replicate and build on published results. Please note that publication of your manuscript 
implicates that you must make all materials, data, computer code, and protocols associated with the publication available to readers. Please disclose at the submission stage any restrictions on the availability of materials or information. New methods and protocols should be described in detail while well-established methods can be briefly described and appropriately cited.

\section{Data, variables and method}

This study aims to investigate the role of conflict between farmers and their main buyer in the effects of relationship quality (satisfaction, commitment, and trust) on contract farming. The results of this paper seek to enrich the literature in this field by providing additional insights in favour or not of the above relationships.

The study is based on a survey of farmers operating in different areas in Albania. Initially and literature review is done to identify the research gaps and then to design a questionnaire. The questionnaire covers basic information about the farm structure and production, farm household demographics, and a module dedicated to the relationships between the farmer and its buyers, which offer the right way to test the proposed hypotheses. The data collection is done during December 2019 and January 2020. Table 1 informs on profile of the sample.

Contract farming is measured with a dichotomous dummy variable, where a farmer that has a prior agreement with the main buyer was coded 1, and 0 otherwise. On the other hand, conflict was measured as a composite variable of four statements answering to the question "how easy it is to agree with the buyer about...?" which are: Level of price, Product characteristics, Costs of transportation to the buyer, Standard/Quality of product. The possible answer to each of these statements were: $1=$ Very easy, $2=$ Easy, $3=$ Neither easy nor difficult, 4 = Difficult, 5 =Very difficult.

\section{Conducting research and results}

Through the quantitative part of the research, the focus was on data collecting, processing, and analysis. A nine-level Likert scale was used to measure the perceptions and assessments of the respondents, on the dependent variable (transitional crisis), as well as the independent variables (heritage of socialism, geopolitics, nomenclature authorities, deficit of institutional changes, and neoliberal ideology), in a survey that was applied during the research. In measuring the dependent variable (transitional crisis), the scale marks were set from the lowest (1) to the highest (5). Regarding the independent variables, the negative impact was measured from the minimum negative (1) to the maximum (5) on the dependent variable. The survey included filling out 500 questionnaires for each country (Montenegro, Serbia, and Bosnia and Herzegovina), which made a total of 1,500 respondents. Collected data for this study were processed by SPSS software. According to the purpose defined in the hypothesis of work, descriptive statistics were used for the data analysis, correlation analysis, and multi-correlation. The multiple linear regression model was applied after (the method of least square), as well as hierarchical multiple regression model. 
Table 1. Sample profile

\begin{tabular}{llcc}
\hline Variable & Category & Count & Column N \% \\
\hline Gender & Female & 275 & $43 \%$ \\
\hline Age of the respondent & Male & 365 & $57 \%$ \\
\cline { 2 - 4 } & $25-34$ years old & 36 & $5.59 \%$ \\
\cline { 2 - 4 } & $35-44$ years old & 42 & $6.61 \%$ \\
\cline { 2 - 4 } & $45-54$ years old & 148 & $23.10 \%$ \\
\cline { 2 - 4 } & 55-64 years old & 191 & $29.79 \%$ \\
\cline { 2 - 4 } Education of the respondent & 65 years old & 224 & $34.92 \%$ \\
\cline { 2 - 4 } & Elementary-up to 4 years & 43 & $6.66 \%$ \\
\cline { 2 - 4 } & Secondary-8/9 years & 353 & $55.18 \%$ \\
\cline { 2 - 4 } & High School & 163 & $25.51 \%$ \\
\cline { 2 - 4 } & Professional High School & 58 & $9.14 \%$ \\
\cline { 2 - 4 } & University & 22 & $3.51 \%$ \\
\hline Municipality & Has & 14 & $2.2 \%$ \\
\cline { 2 - 4 } & Ura Vajgurore & 15 & $2.4 \%$ \\
\cline { 2 - 4 } & Maliq & 153 & $24.7 \%$ \\
\cline { 2 - 4 } & Lushnje & 155 & \\
\cline { 2 - 4 } & Konispol & & $25 \%$ \\
\hline
\end{tabular}

Source: own compilation

Relationship quality covers three variables, which are: satisfaction, commitment, and trust. Satisfaction is measured using a 5-Likert scale, where the options for this question "how satisfied or unhappy are you with each of the elements regarding trade relations with your buyer" are: Level of information exchange, Offered price, Level of sales and Fairness of earnings distribution (between you and the buyer). Commitment and trust were measured with different sets of statements answering to the main question "please indicate how much you agree or disagree with each of the below sentences" on a 5-point Likert scale: $1=$ I do not agree at all, $2=\mathrm{I}$ don't agree, $3=$ Somewhat agree, $4=$ I agree, $5=$ I agree very much.

To test the direct and indirect effects of relationship quality and conflict on contract farming, the partial least squares method of structural equation modelling (PLS-SEM) was employed (Hair, Hult, Ringle \& Sarstedt, 2017). It was used this method because this type of study requires unobserved variables to follow-up analysis (Hair, Risher, Sarstedt, \& Ringle, 2019). Constructs were measured as reflective indicators. The method of PLS-SEM was done in SmartPLS 3.0 (Ringle, Wende, \& Becker, 2015). As it is suggested, bootstrap procedure with 5000 iterations of resampling was done to evaluate the value of the standardized paths between the measured constructs (Hair et al., 2017).

\section{Empirical results}

Before testing the formulated hypotheses, a preliminary analysis was carried out. Spatial attention was given to the assumptions of the PLS-SEM method, such as collinearity, loading, scale reliability, and discriminant validity among constructs. The loadings were found to be above 0.80 (see Table 2), which is a value above the conservative threshold of 0.70 . In the same table, per each indicator is reported the variance inflation factor (VIF) values, which are below the threshold of 3 , meaning that there was no multicollinearity issue. 
Table 2. Model measurement

\begin{tabular}{llrr}
\hline Construct & Statements & Loading & VIF \\
\hline Commitment & $\begin{array}{l}\text { I would like to strengthen the business relationship with the } \\
\text { main buyer in the future }\end{array}$ & 0.856 & 1.994 \\
\cline { 2 - 4 } & $\begin{array}{l}\text { I believe that in the long term the relationship with the principal } \\
\text { purchaser will be profitable }\end{array}$ & 0.892 & 2.231 \\
& $\begin{array}{l}\text { I would find it easy to replace the business relationship with the } \\
\text { main buyer }\end{array}$ & 0.889 & 2.118 \\
& Level of prices & 0.822 & 2.012 \\
\hline \multirow{2}{*}{ Conflict } & Product characteristics & 0.892 & 2.736 \\
\cline { 2 - 4 } & Costs of transportation to the buyer & 0.851 & 2.075 \\
\cline { 2 - 4 } & Standard/Quality of product & 0.867 & 2.394 \\
\hline Satisfaction & Level of information exchange & 0.868 & 2.196 \\
\cline { 2 - 4 } & Offered Price & 0.810 & 1.990 \\
\cline { 2 - 4 } & Level of Sales & 0.835 & 2.029 \\
\cline { 2 - 4 } & Fairness of Earnings Distribution (between you and the buyer) & 2.035 \\
\hline Trust & I trust the information the buyer gives me (e.g. market prices) & 0.891 & 2.759 \\
\cline { 2 - 4 } & $\begin{array}{l}\text { Generally, my primary buyer does not take actions that could } \\
\text { harm my business }\end{array}$ & 0.826 & 2.160 \\
\cline { 2 - 4 } & I trust my buyer & 0.856 & 2.177 \\
\cline { 2 - 4 } & The promises made by my buyer are reliable & 0.865 & 2.324 \\
\hline
\end{tabular}

Source: own calculation

In Table 3 are shown the results of the reliability analysis for the constructs of the present study. The result of the analysis indicates that the four latent variables reflect reasonable scale reliability since the Cronbach's alpha and composite reliability values ranged in between 0.70 and 0.95 . Furthermore, it was found that the latent variables were distinct from one another since discriminant analysis has shown that all the Heterotrait-Monotrait values were smaller than 0.85 (Henseler, Ringle, \& Sarstedt, 2015) (see Table 4). Taking all together, based on Hair et al.'s (2019) guidance, the PLS-SEM assumptions were not violated. Hence the results generated by the PLS-SEM method are robust and so can be interpreted.

Table 3. Reliability analysis

\begin{tabular}{lccc}
\hline & Cronbach's Alpha & rho_A & Composite Reliability \\
\hline COM & 0.853 & 0.859 & 0.911 \\
\hline CONF & 0.881 & 0.884 & 0.918 \\
\hline SAT & 0.864 & 0.876 & 0.907 \\
\hline TR & 0.882 & 0.887 & 0.919 \\
\hline
\end{tabular}

Note: COM, Commitment; CONF, Conflict; SAT, Satisfaction; TR, Trust.

Source: own calculation

Table 4. Discriminant analysis and correlation coefficients

\begin{tabular}{llllc}
\hline & COM & CONF & SAT & TR \\
\hline COM & & -0.343 & 0.548 & 0.730 \\
\hline CONF & 0.396 & & -0.492 & -0.522 \\
\hline SAT & 0.637 & 0.554 & & 0.713 \\
\hline TR & 0.847 & 0.588 & 0.813 & \\
\hline
\end{tabular}

Note: COM, Commitment; CONF, Conflict; SAT, Satisfaction; TR, Trust. Correlation above, HTMT below Source: own calculation 
The results of the structural model are summarized in Table 5 and 6 . The model explains $30.6 \%$ of the variation in conflict and almost 4 percent in contract farming. Regarding the direct influences, with the exclusion of the effects of commitment $(\beta=-0.001, p>0.10)$ and satisfaction $(\beta=-0.004, p>0.10)$ on contract farming, all other relationships were found to be statistically significant. Hence, conflict was significantly influenced by the relationship quality, specifically, satisfaction $(\beta=-0.252, p<0.001)$, commitment $(\beta=0.104, p<0.05)$, and trust $(\beta$ $=-0.421, p<0.001)$. On the other hand, contract farming was directly affected by trust $(\beta=$ $0.223, p<0.001)$ and conflict $(\beta=0.141, p<0.05)$. Based on these results, it can be concluded that evidence supports $\mathrm{H} 1 \mathrm{c}$ and $\mathrm{H} 2$ and rejects $\mathrm{H} 1 \mathrm{a}$ and $\mathrm{H} 1 \mathrm{~b}$.

Regarding the indirect effects, it was found that conflict statistically mediates the effects of satisfaction $(\beta=-0.035, p<0.001)$ and trust $(\beta=-0.059, p<0.01)$ on contract farming. However, the analysis showed that the effect of commitment on contract farming is not mediated by conflict $(\beta=0.015, p>0.10)$. Thus, significant evidence was found in supporting $\mathrm{H} 3 \mathrm{a}$ and $\mathrm{H} 3 \mathrm{c}$, while $\mathrm{H} 3 \mathrm{~b}$ was rejected. These results emphasise the role of conflict in governing the effect of satisfaction and trust on contract farming.

Table 5. R-squares of the relationships

\begin{tabular}{lcc}
\hline & R Square & R Square Adjusted \\
\hline CONF & 0.306 & 0.303 \\
\hline contract & 0.036 & 0.030 \\
\hline
\end{tabular}

Note: CONF, Conflict; Contract, Contract farming.

Source: own calculation

Table 6. Hypotheses testing

\begin{tabular}{lllccc}
\hline Effect & Hypothesis & Path & Coefficient & $t$ & $p$ \\
\hline Direct & H1a & SAT -> contract & -0.004 & 0.057 & 0.955 \\
\hline & H1b & COM -> contract & -0.001 & 0.025 & 0.980 \\
\hline & H1c & TR - > contract & 0.223 & 3.272 & 0.001 \\
\hline & SAT - C CONF & -0.252 & 5.372 & 0.000 \\
\hline & COM - CONF & 0.104 & 2.240 & 0.025 \\
\hline & TR - CONF & -0.421 & 8.046 & 0.000 \\
\hline Indirect & H2 & CONF -> contract & 0.141 & 2.339 & 0.019 \\
\hline & H3b & COM -> CONF -> contract & 0.015 & 1.613 & 0.107 \\
\hline & SAT -> CONF -> contract & -0.035 & 2.145 & 0.032 \\
\hline & H3c & TR -> CONF -> contract & -0.059 & 2.149 & 0.032 \\
\hline
\end{tabular}

Note: COM, Commitment; CONF, Conflict; SAT, Satisfaction; TR, Trust; Contract, Contract farming.

Source: own calculation

\section{Discussion}

This research has shown useful insights regarding the role of conflict between trading partners in the influences of relationship quality (satisfaction, commitment, and trust) on contract farming. From a competitive advantage perspective, it is known that the relationship between trading partners is a source of competitive (Corsten \& Felde, 2005; Ercsey, 2017; O'Toole \& Donaldson, 2000; Xhoxhi et al., 2018). Thus, performing good relationships with the partners leads to better position in terms of competitive advantage. In this line of logic, conflict between trading partners reduces the level of competitive advantage.

Findings are discussed based on the type of effect: direct or indirect. Regarding the direct effects, it is interesting that satisfaction and commitment are found to be insignificant factors for contract farming, while trust positively influences to the farmer in having a prior 
agreement with its main buyer. Having trust in the relationship with the partners in trading increases the chances to contract the product. Therefore, the findings show that farmers with higher trust are more prone to contract farming compared to those with low trust in the trading relationship. This finding is in line with previous studies (Xhoxhi, Keco, Skreli, Imami, \& Musabelliu, 2019; Zhang \& Hu, 2011). Findings about the effect of satisfaction on contract farming contradict prior research, which has stated a significant positive relationship of the factors, such as contributions from Dedehouanou (2013), Dlamini-Mazibuko et al. (2019), Keco et al. (2019) etc. Similarly, the finding regarding farmer's commitment in the relationship with the partners contradicts what is hypothesized based on the literature review (Macchiavello \& Morjaria, 2015; Xhoxhi et al., 2014).

Another direct effect that is hypothesized following the literature review is the one that links the conflict between trading partners to contract farming. The results indicate that contract farming has higher chances to occur in cases when the conflict between trading partners is higher. This result can be supported based on this logic: having a conflictual relationship with the partner leads to less trust, which imposes the need of a verbal written contract.

The second group of hypotheses consists of indirect effects. Indirect effect is known as the mediated effect of one factor over the relationship between two other factors. The mediator factor in this study is conflict in the trading relationships. There are three indirect effects that are tested in this research paper. Firstly, the findings show that conflict between trading parties mediates the influence of farmer's satisfaction on contract farming. This insight might be the real reason why the direct effect of satisfaction on contract farming was insignificant, by pointing out the role of conflict in this regard. Secondly, the conflict between trading partners does not mediate the influence of farmer's commitment to contract farming, meaning that the conflict does not govern the relationship between the farmer's commitment and contract farming. Thirdly, the effect of farmer's trust in the relationship of contract farming is mediated by conflict between trading partners. This insight compliments the direct effect of trust on contract farming.

\section{Conclusion}

The aim of this research was to explore the role of conflict between trading parties in contract farming. Moreover, this role is extending to the mediating effect that such conflicts may have over the influences of farmer's satisfaction, commitment and trust in the relationship with the main buyer on contract farming, which represents the novelty of this study. Given the fact that having less conflict between trading partners may lead to higher competitive advantages, it can be stated that by building a good relationship between partners in trading better results can be achieved. Therefore, there is a need to better understand such role in the context of a developing country like Albania (Çera et al., 2019). This study aims to create a better picture over this puzzle.

The study concludes that farmers are more prone to contract the product as the conflict between trading parties increases. In addition, the study's findings show that conflict between trading partners governs the influences of farmer's satisfaction and trust in the relationship with the main buyer on contract farming. On the other hand, conflict between trading parties does not mediate the effect of farmer's commitment in the relationship with its buyer to contract farming. However, it is fair to say that Albania can be considered as a separate case, at least compared to developed countries. In terms of culture and traditions, Albania differs a lot from other developing countries. Consequently, this paper's findings cannot be generalized for countries overseas. 


\section{References}

Alkhurshan, M., \& Rjoub, H. (2020). The scope of an integrated analysis of trust, switching barriers, customer satisfaction, and loyalty. Journal of Competitiveness, 12(2), 5-21. https://doi.org/10.7441/joc.2020.02.01

Batt, P. J., \& Rexha, N. (2000). Building Trust in Agribusiness Supply Chains. Journal of International Food \& Agribusiness Marketing, 11(1), 1-17. https://doi.org/10.1300/j047v11n01_01

Bellemare, M. F. (2012). As You Sow, So Shall You Reap: The Welfare Impacts of Contract Farming. World Development, 40(7), 1418-1434. https://doi.org/10.1016/j.worlddev.2011.12.008

Bencsik, A., Jakubik, M., \& Juhasz, T. (2020). The economic consequences of trust and distrust in knowledge-intensive organizations. Journal of Competitiveness, 12(3), 28-46. https://doi.org/10.7441/joc.2020.03.02

Bencsik, A., Kosár, T.S., \& Machová, R. (2018). Corporate culture in service companies that support knowledge sharing. Journal of Tourism and Services 9(16): 7-13. https://doi.org/10.29036/jots.v9i16.41

Bilan, Y., Mishchuk, H., Samoliuk, N., \& Mishchuk, V. (2020). Gender discrimination and its links with compensations and benefits practices in enterprises. Entrepreneurial Business and Economics Review, 8(3), 189-204. https://doi.org/10.15678/EBER.2020.080311

Birthal, P. (2008). Making contract farming work in smallholder agriculture. In Contract Farming in India: A Resource Book (pp. 1-16). Indian Council of Agricultural Research.

Çera, G., Breckova, P., Çera, E., \& Rozsa, Z. (2019). The effect of business enabling policies, tax treatment, corruption and political connections on business climate. Acta Polytechnica Hungarica, 16(4), 113-132. https://doi.org/10.12700/APH.16.4.2019.4.6

Çera, G., Meço, M., Çera, E., \& Maloku, S. (2019). The effect of institutional constraints and business network on trust in government: An institutional perspective. Administration \& Public Management Review, 33, 6-19. https://doi.org/10.24818/amp/2019.33-01

Clampit, J., Kedia, B., Fabian, F., \& Gaffney, N. (2015). Offshoring satisfaction: The role of partnership credibility and cultural complementarity. Journal of World Business, 50(1), 79-93. https://doi.org/10.1016/j.jwb.2014.02.001

Corsten, D., \& Felde, J. (2005). Exploring the performance effects of key-supplier collaboration: An empirical investigation into Swiss buyer-supplier relationships. International Journal of Physical Distribution and Logistics Management, 35(6), 445461. https://doi.org/10.1108/09600030510611666

Daviron, B. (2002). Small farm production and the standardization of tropical products. Journal of Agrarian Change, 2(2), 162-184. https://doi.org/10.1111/1471-0366.00029

Dedehouanou, S. F. A., Swinnen, J., \& Maertens, M. (2013). Does contracting make farmers happy? Evidence from Senegal. Review of Income and Wealth, 59(SUPPL1). https://doi.org/10.1111/roiw.12041

Dlamini-Mazibuko, B. P., Ferrer, S., \& Ortmann, G. (2019). Examining the farmer-buyer relationships in vegetable marketing channels in Eswatini. Agrekon, 58(3), 369-386. https://doi.org/10.1080/03031853.2019.1596824

Ercsey, I. (2017). The Role of Customers' Involvement in Value Co-creation Behaviour is Value Co-creation the Source of Competitive Advantage? Journal of Competitiveness, 9(3), 51-66. https://doi.org/10.7441/joc.2017.03.04

Evteeva, T., Rovný, P., \& Petril'ák, M. (2019). Farm as a form of small agricultural business in Russia: advantages and disadvantages. International Journal of Entrepreneurial Knowledge, 7(2), 53-62. https://doi.org/10.37335/ijek.v7i2.93 
Fritz, M., \& Fischer, C. (2007). The role of trust in European food chains: Theory and empirical findings. International Food and Agribusiness Management Review, 10(2), 141-161. https://doi.org/10.22004/ag.econ.8185

Gorb, O. (2017). Solving the problem of concentration of agricultural lands by agricultural holdings from the perspective of rural development. Economics, Management and Sustainability, 2(2), 79-85. https://doi.org/10.14254/jems.2017.2-2.8

Griffith, D. A., Hu, M. Y., \& Ryans, J. K. (2000). Process Standardization across and Relationships, 303-324.

Grosh, B. (1994). Contract farming in Africa: an application of the new institutional economics. Journal of African Economies, 3(2), 231-261. Retrieved from https://academic.oup.com/jae/article-abstract/3/2/231/704019

Hair, J. F., Hult, G. T. M., Ringle, C. M., \& Sarstedt, M. (2017). A Primer on Partial Least Squares Structural Equation Modeling (2nd ed.). Los Angelos: Sage.

Hair, J. F., Risher, J. J., Sarstedt, M., \& Ringle, C. M. (2019). When to use and how to report the results of PLS-SEM. European Business Review, 31(1), 2-24. https://doi.org/10.1108/EBR-11-2018-0203

Hartmann, M., Frohberg, K., \& Fischer, C. (2010). Building sustainable relationships in agrifood chains: challenges from farm to retail. In Agri-food chain relationships (pp. 25-44).

Retrieved

from

https://books.google.com/books?hl=en\&lr=\&id=sV7_B6HCrWEC\&oi=fnd\&pg=PA25

$\& d q=$ Building+sustainable+relationships+in+agri-

food+chains:+challenges+from+farm+to+retail\&ots=QYW_-

ZaSYb\&sig=xXzoGySQcMsW1hWoI-CsR-iw0-I

Henseler, J., Ringle, C. M., \& Sarstedt, M. (2015). A new criterion for assessing discriminant validity in variance-based structural equation modeling. Journal of the Academy of Marketing Science, 43(1), 115-135. https://doi.org/10.1007/s11747-014-0403-8

Ik, M., \& Azeez, A. A. (2020). Organisational green behavioural change: The role of Change Management. International Journal of Entrepreneurial Knowledge, 8(1), 34-48. https://doi.org/10.37335/ijek.v8i2.98

Johnston, D. A., McCutcheon, D. M., Stuart, F. I., \& Kerwood, H. (2004). Effects of supplier trust on performance of cooperative supplier relationships. Journal of Operations Management, 22(1), 23-38. https://doi.org/10.1016/j.jom.2003.12.001

Kanji, G. K., \& Wong, A. (1999). Business Excellence model for supply chain management. Total Quality Management, 10(8), 1147-1168. https://doi.org/10.1080/0954412997127

Kaur, G., Sharma, R. D., \& Mahajan, N. (2012). Exploring customer switching intentions through relationship marketing paradigm. International Journal of Bank Marketing, 30(4), 280-302. https://doi.org/10.1108/02652321211236914

Keco, R., Xhoxhi, O., Skreli, E., \& Imami, D. (2019). To contract or not contract: Implications for farmer-buyer trading relation performance. International Journal on Food System Dynamics, 10(2), 151-161. https://doi.org/10.18461/ijfsd.v10i2.09

Kóródi, M., \& Dávid, L.D. (2019). The uniqueness of the hungarian rural tourism supply. Journal of Tourism and Services, 10(19): 24-39. https://doi.org/10.29036/jots.v10i19.93

Kot, S., Haque, A. U., \& Baloch, A. (2020). Supply chain management in SMEs: Global perspective. Montenegrin Journal of Economics, 16(1), 87-104.

Laeequddin, M., Sahay, B. S., Sahay, V., \& Waheed, K. A. (2012). Trust building in supply chain partners relationship: An integrated conceptual model. Journal of Management Development, 31(6), 550-564. https://doi.org/10.1108/02621711211230858

Li, F., \& Nicholls, J. A. F. (2000). Transactional or Relationship Marketing: Detenninants of Strategic Choices. Journal of Marketing Management, 16(5), 449-464. https://doi.org/10.1362/026725700785046001 
Lu, H., Feng, S., Trienekens, J. H., \& Omta, S. W. F. (2012). Network strength, transactionspecific investments, inter-personal trust, and relationship satisfaction in Chinese agrifood SMEs. China Agricultural Economic Review, 4(3), 363-378. https://doi.org/10.1108/17561371211263374

Macchiavello, R., \& Morjaria, A. (2015). The Value of Relationships: Evidence from a Supply Shock to Kenyan Rose Exports. American Economic Review, 105(9), 2911-2945. https://doi.org/10.1257/aer.20120141

Masuku, M. B., \& Kirsten, J. F. (2004). The role of trust in the performance of supply chains: A dyad analysis of smallholder farmers and processing firms in the sugar industry in Swaziland. Agrekon, 43(2), 147-161. https://doi.org/10.1080/03031853.2004.9523642

Muo, I., \& Azeez, A.. (2019). Green Entrepreneurship: Literature Review and Agenda for Future Research. International Journal of Entrepreneurial Knowledge, 7(2), 17-29. https://doi.org/10.37335/ijek.v7i2.90

Naidu, S. (2016). Building and Managing Long-term Buyer-Seller Relationships in Contract Farming. In International Food and Agribusiness Management Association's (IFAMA) 26th Annual World Forum and Symposium (pp. 25-36). Aarhus: IFAMA.

Oláh, J., Hidayat Y.A., Popp, J., Lakner, Z., \& Kovács, S. (2021). Integrative trust and innovation on financial performance in disruptive era. Economics and Sociology, 14(2), 111-136. doi:10.14254/2071-789X.2021/14-2/6

O’Toole, T., \& Donaldson, B. (2000). Relationship Governance Structures and Performance. Journal of Marketing Management, 16(4), 327-341. https://doi.org/10.1362/026725700784772862

Piricz, N. (2018). Affecting determinants of trust in business relationships. Serbian Journal of Management, 13(2), 281-291. https://doi.org/10.5937/sjm13-16649

Polinkevych, O., Khovrak, I., Trynchuk, V., Klapkiv, Y., \& Volynets, I. (2021). Business risk management in times of crises and pandemics. Montenegrin Journal of Economics, 17(3), 99-110.

Ringle, C. M., Wende, S., \& Becker, J.-M. (2015). SmartPLS. Boenningstedt: SmartPLS $\mathrm{GmbH}$. Retrieved from http://www.smartpls.com

Shamdasani, P. N., \& Sheth, J. N. (1994). An experimental approach to investigating satisfaction and continuity in marketing alliances. European Journal of Marketing, 29(4), 6-23. https://doi.org/http://dx.doi.org/10.1108/03090569510086620

Simmons, P. (2002). Overview of Smallholder Contract Farming in Developing Countries. Agricultural and Development Economics Division of the Food and Agriculture Organization of the United Nations (FAO--ESA), Working Papers:, 27.

Tarí, J. J., Pereira-Moliner, J., Molina-Azorín, J. F., \& López-Gamero, M. D. (2020). A Taxonomy of Quality Standard Adoption: Its Relationship with Quality Management and Performance in Tourism Organizations In Spain. Journal of Tourism and Services, 11(21), 22-37. https://doi.org/10.29036/jots.v11i21.151

Theron, E., \& Terblanche, N. S. (2010). Dimensions of relationship marketing in business-tobusiness financial services. International Journal of Market Research, 52(3), 1-16. https://doi.org/10.2501/S1470785310201326

Vo, H. D., Van, T. H. L., Dinh, T. H. L., \& Ho, M. C. (2020). Financial inclusion, corporate social responsibility and customer loyalty in the banking sector in Vietnam. Journal of International Studies, 13(4), 9-23. doi:10.14254/2071-8330.2020/13-4/1

Voldnes, G., Grønhaug, K., \& Nilssen, F. (2012). Satisfaction in buyer-seller relationshipsInfluence of cultural differences. Industrial Marketing Management, 41(7), 1081-1093. https://doi.org/10.1016/j.indmarman.2012.03.001 
Wang, H. H., Wang, Y., \& Delgado, M. S. (2014). The transition to modern agriculture: Contract farming in developing economies. American Journal of Agricultural Economics, 96(5), 1257-1271. https://doi.org/10.1093/ajae/aau036

Wang, H. H., Zhang, Y., \& Wu, L. (2011). Is contract farming a risk management instrument for Chinese farmers?: Evidence from a survey of vegetable farmers in Shandong. China Agricultural Economic Review, 3(4), 489-504. https://doi.org/10.1108/17561371111192347

Williamson, O. E. (1979). Transaction-Cost Economics: The Governance of Contractual Relations. The Journal of Law and Economics, 22(2), 233-261. https://doi.org/10.1086/466942

Wong, A., Tjosvold, D., \& Zhang, P. (2005). Developing relationships in strategic alliances: Commitment to quality and cooperative interdependence. Industrial Marketing Management, 34(7), 722-731. Retrieved from https://www.sciencedirect.com/science/article/pii/S0019850104001592?casa_token=xm irdZMKGMUAAAAA:ATdr3HRJDqOp31b9T5GQoItGdXdzcEhhcYVTdJoDgqx3EM dmJzZfHtheRLDCmsjKHTHywPCw

Xhoxhi, O., Keco, R., Skreli, E., Imami, D., \& Musabelliu, B. (2019). The role of intermediaries' power on contracting decision between farmers and intermediaries. New Medit, 18(3), 3-15. https://doi.org/10.30682/nm1903a

Xhoxhi, O., Pedersen, S. M., \& Lind, K. M. (2018). How does the intermediaries' power affect farmers-intermediaries' trading relationship performance? World Development Perspectives, 10-12, 44-50. https://doi.org/10.1016/j.wdp.2018.09.004

Xhoxhi, O., Pedersen, S. M., Lind, K. M., \& Yazar, A. (2014). The determinants of intermediaries' power over farmers' margin-related activities: Evidence from Adana, Turkey. World Development, $64, \quad 815-827$. https://doi.org/10.1016/j.worlddev.2014.07.012

Xhoxhi, O., Stefanllari, A., Skreli, E., \& Imami, D. (2020). How intermediaries' power affects contract farming decisions: evidence from the medicinal and aromatic plant sector in Albania. Journal of Agribusiness in Developing and Emerging Economies, 10(5), 529544. https://doi.org/10.1108/JADEE-03-2019-0035

Zhang, X., \& Hu, D. (2011). Farmer-buyer relationships in China: the effects of contracts, trust and market environment. China Agricultural Economic Review, 3(1), 42-53. https://doi.org/10.1108/17561371111103534 